\title{
Genetic variation in the porcine myogenin gene locus
}

\section{Journal Article}

\section{Author(s):}

Soumillion, Ann; Erkens, Jo H. F.; Lenstra, Johannes A.; Rettenberger, Günther; Te Pas, Marinus F. W.

Publication date:

1997

Permanent link:

https://doi.org/10.3929/ethz-b-000422869

\section{Rights / license:}

In Copyright - Non-Commercial Use Permitted

\section{Originally published in:}

Mammalian Genome 8(8), https://doi.org/10.1007/s003359900504 


\title{
Genetic variation in the porcine myogenin gene locus
}

\author{
Ann Soumillion, ${ }^{1}$ Jo H.F. Erkens, ${ }^{1}$ Johannes A. Lenstra, ${ }^{2}$ Günther Rettenberger, ${ }^{3}$ Marinus F.W. te Pas ${ }^{1}$ \\ ${ }^{1}$ DLO-Institute for Animal Science and Health (ID-DLO), P.O. Box 65, 8200 AB Lelystad, The Netherlands \\ ${ }^{2}$ Institute of Infectious Diseases and Immunology, Faculty of Veterinary Medicine, Utrecht University, P.O. Box 80.165, 3508 TD \\ Utrecht, The Netherlands \\ ${ }^{3}$ Swiss Federal Institute of Technology, Department of Animal Science, ETH-Zentrum TAN, 8092 Zurich, Switzerland
}

Received 13 October 1996 / Accepted: 16 March 1992

\begin{abstract}
The myogenin ( $M Y O G)$ gene fulfills a key function in muscle differentiation by controlling the onset of myoblast fusion and the establishment of myofibers. In meat-producing animals like pigs and cattle, myofiber numbers have been related to growth capacity. We have characterized the porcine $M Y O G$ gene to detect genetic variation at this locus and to relate it to growth characteristics. $M Y O G$ gene fragments were isolated by PCR on genomic DNA and by screening a genomic library with a mixture of the four human MyoD cDNA fragments. Both the exons and promoter region were very similar to the human and mouse genes. Southern blot analysis of 105 unrelated pigs revealed three polymorphic $M s p I$ sites, located in the promoter region, the second intron, and at the $3^{\prime}$ side of the gene. PCR-RFLP tests detecting four $M Y O G$ alleles were developed. PCR analysis of a panel of pig-rodent somatic cell hybrids confirmed the genetic localization of $M Y O G$ on pig Chromosome (Chr) 9. The PCR-RFLP tests and microsatellite markers on Chr 9 offer the possibility to genotype large numbers of pigs for studies of genetic linkage to meat deposition and growth characteristics.
\end{abstract}

\section{Introduction}

The MyoD gene family consists of four structurally related genes, $M Y O D 1, M Y O G, M Y F 5$, and MYF6. These genes encode basic helix-loop-helix (bHLH) proteins and are involved in muscle cell determination and differentiation in vitro (Olson 1990; Weintraub et al. 1991) as well as in vivo (Lyons and Buckingham 1992). $M Y O G$ is the only MyoD gene expressed in all skeletal muscle cell lines (Wright et al. 1989; Edmondson and Olson 1989). Knock-out experiments in mice have shown that this protein fulfills an essential function in muscle differentiation by regulating the onset of myoblast fusion and the formation of functional muscle fibers (Hasty et al. 1993; Nabeshima et al. 1993).

Breeding in meat-producing animals focuses on growth and lean meat deposition. In pigs, the number of muscle fibers at birth appears to determine the maximal lean meat growth capacity (Händel and Stickland 1984, 1988). Meat production capacity seems to be determined also in cattle by the number of embryonically developed myocytes, since double-muscled cattle show a higher number of prenatally developed myofibers than other cattle (Swatland and Kiefer 1974; Hanset et al. 1982). The central role of $M Y O G$ in the process of muscle differentiation suggests that genetic variation in this locus may be associated with differences in myoblast and myofiber numbers. To initiate the investigation into

\section{Correspondence to: M.F.W. te Pas}

The nucleotide sequence data reported in this paper have been submitted to the EMBL data base and have been assigned the accession numbers X89007 (porcine myogenin gene), X89209 ( $3^{\prime}$ polymorfic site), and X89210 (CA-repeat). the influence of different $M Y O G$ alleles on the muscle development and growth characteristics of pigs, we have isolated genomic MYOG fragments and characterized four haplotypes based on MspI sites. A fast PCR-RFLP test now offers the possibility to perform association studies with growth characteristics (Te Pas and Visscher 1994).

\section{Materials and methods}

Isolation of genomic DNA. Genomic DNA was isolated from EDTAtreated blood samples and stored at $-80^{\circ} \mathrm{C}$, following standard procedures (Sambrook et al. 1989).

PCR amplification of genomic MYOG fragments. MYOG-specific PCR amplifications were performed on $50 \mathrm{ng}$ genomic DNA in $50-\mu \mathrm{l}$ reactions containing 1.25 U Taq polymerase (Perkin Elmer Cetus, Norwalk, Conn.) or $0.2 \mathrm{U}$ Super Tth polymerase (SphaeroQ, Leiden, The Netherlands) in the appropriate buffer, 20 pmole of both primers, and 0.2 mM of each dNTP (Boehringer Mannheim, Germany). Primer sequences and reaction conditions are specified in Table 1.

Cloning and sequencing of MYOG fragments. PCR1 and PCR2 amplification products (Table 1) were cloned into pUC18 or $\mathrm{pBS}^{-}$plasmid and sequenced by standard molecular biology technology (Sambrook et al. 1989).

Screening of a porcine genomic library. A total of $0.5 \times 10^{6}$ plaqueforming units (pfu) of a porcine genomic library in the phage vector EMBL3/SP6/T7 (Clontech Laboratories Inc., Palo Alto, Calif.) were screened by hybridization to a mixture of the four radioactive labeled human MyoD cDNA fragments (ATCC, Rockville, Md.; Braun et al. 1989a, 1989b, 1990). Positive clones were isolated by three successive rounds of plaque purification. Phage DNA was isolated according to the manufacturer's recommendations by standard molecular biology technology (Sambrook et al. 1989).

MYOG-containing phage clones were identified by PCR amplification on $1 \mu l$ of 1:1000 dilution of the DNA stocks, by use of PCR 1 or PCR3 (Table 1). Fragments of two phage clones were subcloned for sequence analysis by standard molecular biology technology (Sambrook et al. 1989).

Southern blotting and RFLP analysis of porcine genomic DNA. Ten microgram of porcine genomic DNA was digested with $100 \mathrm{U} M s p \mathrm{I}$ (Boehringer) for $16 \mathrm{~h}$ at $37^{\circ} \mathrm{C}$, electrophoresed in a $0.8 \%$ (wt/vol) agarose gel, and transferred to positively charged nylon membranes (Boehringer) by Southern blotting (Southern 1975). Membranes were hybridized to radioactive labeled MYOG genomic fragments following the manufacturer's instructions.

Mapping and PCR-RFLP detection of polymorphic Msp/sites. SacI subclones of MYOG phage clones were digested with $M s p I$ to determine the presence and localization of the $M s p I$ sites. Sequences flanking the $M s p$ I sites were determined. PCR tests were developed for the amplifica- 
Table 1. Primer sequences, annealing temperatures, and fragment characteristics for PCR amplification reactions of different regions of the pig $M Y O G$ gene.

\begin{tabular}{|c|c|c|c|}
\hline Amplified region & Primer sequences $^{\mathrm{a}}$ & $\begin{array}{l}\text { Annealing } \\
\text { temperature } \\
\left({ }^{\circ} \mathrm{C}\right)\end{array}$ & $\begin{array}{l}\text { Predicted size of } \\
\text { amplified product } \\
\text { (bp) }\end{array}$ \\
\hline PCR 1 & FW: $5^{\circ}$-GGAATTCCATGGAGCTGTATGARACATC & & \\
\hline $\begin{array}{l}\text { Coding regions and introns } \\
\text { PCR } 2\end{array}$ & REV: 5' - GGAATTCCAATCTCAGTTGGGCATGGT & 61 & 2099 \\
\hline PCR2 & FW: $5^{\prime}-$ GGAATTCCATGGAGCTGTATGARACATC & & \\
\hline Exon 1 & REV: 5'-TCRCGCTCCTCCTGGTTGA & 61 & 442 \\
\hline PCR 3 & FW: $5^{\prime}$ - CAACCAGGAGGAGCGCGATCTCCG & & \\
\hline Exon 1-Exon 2 & REV: $5^{\circ}$-AGGCGCTGTGGGAGTTGCATTCACT' & $59-61$ & 871 \\
\hline PCR4 & FW: $5^{\circ}-$ TCAGGAAGAACTGAAGGCTG & & \\
\hline $3^{\prime}$-SIDE & REV: $5^{\prime}$-GTTTCCTGGGGTGTTGC & 60 & 353 \\
\hline PCR 5 & FW: $5^{\prime}-$ TCTTGACCTTGTCATTGTGG & & \\
\hline 5'-SIDE & REV: $5^{\prime}-$ - CTTCCTCACACCACCTTAC & 60 & 364 \\
\hline PCR 6 & FW: $5^{\prime}$-GAGTCTCATCTGACTGACAC & & \\
\hline 5'-SIDE & REV: $5^{\circ}-$ TCRCGCTCCTCCTGGTTGA & 60 & 990 \\
\hline
\end{tabular}

FW: forward primer; REV: reverse primer.

${ }^{\mathrm{b}}$ Montarras et al. (1991).

tion and detection of these sites: PCR4 detecting a polymorphic MspI site at the $3^{\prime}$ end of the gene, PCR5 detecting a nonpolymorphic $M s p I$ site in the promoter region, and PCR6 amplifying a promoter fragment diagnostic for the 2.3-kb allele. Ten microliter of the amplification products were digested with $10 \mathrm{U} \mathrm{MspI}$ enzyme at $37^{\circ} \mathrm{C}$ and analyzed on an agarose gel.

Chromosomal localization by somatic cell hybrid analysis. A pigrodent hybrid cell panel consisting of 21 hybrids has been established and characterized by QFQ-banding, FISH, and PCR, as previously described (Rettenberger et al. 1994a, 1994b, 1994c, 1995b). This cell panel was tested for the presence of the $M Y O G$ gene by PCR3, and the distribution pattern of these signals was compared with the distribution pattern of the porcine reference loci for each hybrid. The percentage of hybrids that are identical for the presence of a reference locus and the presence of the porcine $M Y O G$ PCR product is the concordance value for a given chromosome. Concordance and correlation phi $(\phi)$ were statistically evaluated as described by Chevalet and Corpet (1986). In a panel of 20 hybrids, a marker is syntenic with a chromosome/reference locus, with a probability of $2.5 \%$ of making an incorrect decision, if $\phi>0.74$. If $\phi<0.59$, synteny can be excluded, and if $0.59 \leqslant \phi \leqslant 0.74$, no decision can be made.

\section{Results}

Amplification, cloning, and sequence analysis of the porcine MYOG gene. Specific PCR reactions were developed to determine the porcine MYOG sequence (PCR 1 and 2). Primers were based on an alignment of human (Salminen et al. 1991) and mouse MYOG sequences (Edmondson et al. 1992). Fragments of 2081 and 442 bp respectively, covering the complete coding sequences and two introns, were obtained by PCR amplification on pig genomic DNA. These fragments were cloned in pUC18 and sequenced (Fig. 1). Like the human and mouse genes, the pig $M Y O G$ gene has three exons. The first exon encodes the bHLH domans. Exon 2 encodes 27 amino acids of the transactivation domain (Schwarz et al. 1992) and exon 3 the conserved C-terminal segment, common to the four MyoD proteins (Fujisawa-Sehara et al. 1990 ). The amino acid sequence of porcine $M Y O G$ is for $97 \%$ and $96 \%$ identical to the sequence of human and mouse MYOG respectively, while the bHLH region has the same amino acid sequences as in human, mice, and pigs. The porcine introns (785 and $639 \mathrm{bp}$ ) are larger than the corresponding introns of mice (513 and $526 \mathrm{bp}$ ) and humans (131 and $125 \mathrm{bp}$ ).

The MYOG promoter and 3' noncoding sequences were isolated and sequenced with MYOG-positive phage clones. This revealed $571 \mathrm{bp}$ of the promoter sequences and $856 \mathrm{bp}$ of the 3' untranslated region, containing a putative polyadenylation signal (AATAAA) at positions 3397 to 3402 (numbers refer to nucleotide numbers in EMBL database entry X89007). Analysis for the presence of transcription factor binding consensus sequences revealed three E-box sequences (CANNTG) located at positions 508-513

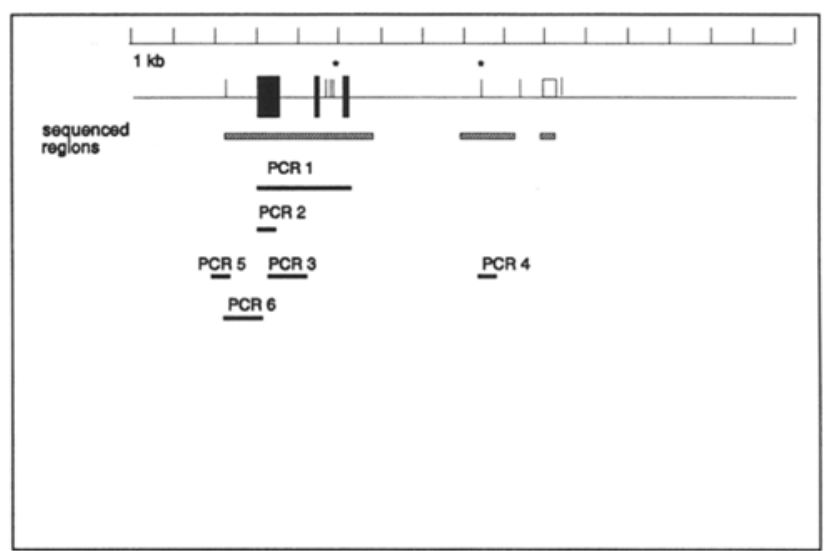

Fig. 1. Structure of the pig MYOG gene. Coding sequences are indicated in black. Open box indicates the position of the CA-repeat. Vertical lines indicate $M s p I$ restriction sites. Polymorphic $M s p I$ restriction sites are indicated by asterisks. The positions of the PCR reactions are indicated.

(E3), 210-215 (E2), and 22-27 (E1). A myocyte-specific enhancer factor 2 (MEF-2) site (456-464), a nuclear factor 1 (NF-1) site (469-481), and a TATA-box sequence (494-498) were identified within $70 \mathrm{bp}$ of the putative transcription start sites. Comparison of the pig sequence with the human and mouse sequences revealed more than $96 \%$ sequence identity within the proximal $160 \mathrm{bp}$ upstream from the transcription start sites.

Characterization of a CA-repeat at the porcine $M Y O G$ gene locus. Hybridization of the MYOG phage inserts with a $(\mathrm{CA})_{25}$-repeat probe revealed the presence of a CA-repeat sequence at about $5 \mathrm{~kb}$ downstream of the TGA termination codon (Fig. 1). Sequence analysis of this region demonstrated that the CA-repeat was interrupted by $\mathrm{CCC}$ stretches.

Characterization of MspI haplotypes at the procine MYOG gene locus. The presence of a variable 4.2/4.9-kb MspI fragment at the MYOG gene locus has been previously described by Emst and associates (1993). Southern blot analysis with a probe specific to the $3^{\prime}$ side of the MYOG gene comprising $195 \mathrm{bp}$ of intron 2 and exon 3 and $4 \mathrm{~kb}$ of $3^{\prime}$ untranslated sequences (Fig. 1), and restriction mapping of MYOG subclones, enabled us to localize the described polymorphic MspI site at the 3'side of the gene and to sequence its flanking regions. A PCR-RFLP test (PCR4) for detection of this polymorphic site was developed and used for genotyping a panel consisting of 105 unrelated pigs from seven breeds (Fig. 2, Table 2, columns 9-11). The Meishan population under 


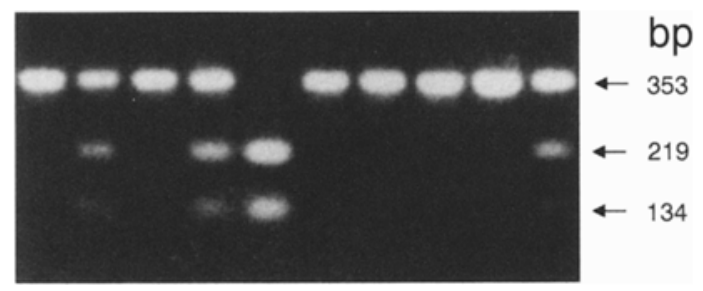

Fig. 2. Detection of a polymorphic $M s p I$ site at the $3^{\prime}$ side of the $M Y O G$ gene in eight Great Yorkshire (GY) boars. A fragment of $353 \mathrm{bp}$ is amplied (PCR4) and digested with $M s p I$, resulting in the 353-bp fragment, or in 134-bp and 219-bp fragments.

investigation does not contain the $4.2-\mathrm{kb}$ allele, but this allele is predominant in Duroc and Wild Pigs. Both alleles were equally present in Pietrain, Dutch Landrace (DL), and Hampshire, while the Great Yorkshire (GY) population was characterized by a high frequency of the $4.9-\mathrm{kb}$ allele.

Furthermore, MspI digestion of PCR1 products of the 105 unrelated pigs revealed sequence variation at position 2394 in the second intron (Fig. 1, Fig. 3) for the Meishan, DL, and Duroc breeds (Table 2, columns 6-8). Southern blotting with the PCR1 fragment as a probe detected in all breeds a $2.3-\mathrm{kb} M s p I$ fragment (Table 2, column 1-3). Only in the Meishan population was a second $1.8-\mathrm{kb}$ fragment also visualized that is coupled to the absence of the $2394 \mathrm{MspI}$ site (see Fig. 3A and Fig. 3B). This indicates a deletion between the $M s p I$ sites or a third variable $M s p I$ site in the promoter region. Since the $M s p I$ site located at the $5^{\prime}$ site of the gene (Fig. 1) can be detected by means of PCR5/MspI digestion in all animals tested, the polymorphic site must be located between this site and the coding region. Amplification of this region appears to be associated with the $2.3-\mathrm{kb}$ allele (Fig. 3). Autosomal Mendelian segregation of the $1.8-\mathrm{kb}$ and $2.3-\mathrm{kb}$ pig $M Y O G$ fragments and of the $M s p I$ polymorphism in the second intron was checked in 58 Meishan pigs from 4 two-generation families and in a DL heterozygous $x$ homozygous cross (nine animals, data not shown). Analysis of the genotypes of the 105 unrelated pigs and of the progeny of the DL cross suggests the presence of at least four different $M Y O G$ haplotypes in pigs (Fig. 4). The allele frequencies depend on the breed, with allele 4 specific for the Meishan breed, allele 3 only in a few DL and Duroc animals, and alleles 1 and 2 predominant in the Western breeds.

Chromosomal assignment of the porcine MYOG gene. We analyzed a pig-rodent somatic cell hybrid panel for the presence or absence of the porcine $M Y O G$ gene by $M Y O G$-specific PCR 3 amplification on genomic DNA. A pig $M Y O G$ fragment with a predicted size of $873 \mathrm{bp}$ was amplifed, together with hamster or mouse fragments of 650 and $600 \mathrm{bp}$ respectively. The porcine PCR3 fragment was further identified by $E c o$ RI and $P v u I I$ digestion, generating fragments of respectively $313+560$ bp and $219+$ $654 \mathrm{bp}$, consistent with the expected length.

The distribution pattern of the porcine MYOG-specific PCR products (Table 3 ) was compared with the distribution patterns of reference loci corresponding to pig chromosomes (Rettenberger et al. 1994a, 1994b, 1994c, 1995b). The highest concordance percentage $(90 \%)$ and phi $(\phi)$ value $(0.81)$ were found for Chr 9 .

\section{Discussion}

The isolation and sequence analysis of the porcine $M Y O G$ gene described here have led to the characterization of genetic variation at this gene locus at three different sites and the identification of at least four different $M Y O G$ haplotypes that can be distinguished by fast PCR-RFLP tests.

We observed high sequence identity in both the coding and regulatory regions, indicating high conservation between pigs, human, and mice. The proximal $160 \mathrm{bp}$ of the promoter region contains the E1-box, which is present in the MYOG gene of human, mice, and pigs and which has been demonstrated to be the only MYOG binding E-box sequence in the mouse promoter (Edmondson et al. 1992). Funk and Wright (1992) identified MEF-2 and NF-1 as stabilizing factors for the in vitro binding of MYOG to E-box sequences. The presence of binding sites for both factors in the highly conserved minimal proximal promoter sequences of the $M Y O G$ genes of different species indicates that these factors are involved in the regulation of the $M Y O G$ expression. Outside this minimal promoter region, some species-specific differences can be found, such as the E2-box, which is conserved only between human and porcine genes. We found no variable sites within the coding and proximal promoter regions, probably because of their functional importance. Comparison of the sequence we describe here with another recently reported sequence of the porcine $M Y O G$ gene (Briley et al. 1995) also shows differences only outside these regions (see the EMBL data base entry X89007).

Association studies require the genetic screening of many animals, showing the need for fast methods like PCR-based tests, rather than time-consuming methods such as Southern-RFLP or sequencing (Te Pas and Visscher 1994). Fast and easily detectable PCR-RFLP tests detecting polymorphic sites near to, but outside the coding and regulatory regions of a gene can be associated with functional sequence divergence of a gene. The number of recombinations between the detected polymorphism and a functional polymorphism depends on their distance. Within a few thousand $\mathrm{bp}$, the recombination percentage will be almost zero. So a PCRRFLP detection of gene-specific haplotypes allows a fast detection of functional polymorphisms in which the same gene is involved (Te Pas and Visscher 1994). We describe the localization of four haplotypes within the porcine $M Y O G$ gene locus that can be detected by PCR-RFLPs with $M s p I$. One $M s p I$ site is located $3^{\prime}$ to the gene, one is situated within the second intron, and a Meishanspecific RFLP is found within the promoter region. The $1.8-\mathrm{kb}$ allele detected by Southern blotting in Meishan appears to be coupled to a failure of the PCR6 reaction, suggesting that the $2.3 / 1.8-\mathrm{kb}$ polymorphism is explained by a deletion within the 2.3-kb fragment.

Analysis of a panel of 105 unrelated pigs from seven different breeds shows that the $3^{\prime}$ polymorphism is found in all breeds tested except the Meishan population, in which only the large allele was found. Ernst and colleagues (1993) found the large allele as the predominant MYOG allele in different Chinese pig breeds (Fengjing, Meishan, Minzu); this might be explained by the very small numbers $(<10)$ of founder animals of these populations in the U.S. and in Europe (E.W. Brascamp, personal communication). The polymorphism in the second intron can be detected in Meishan, Duroc, and Dutch Landrace. In Meishan animals this polymorphism is coupled with another polymorphism in the promoter region. Because of the limited distribution of the polymorphic sites in promoter and second intron, the $3^{\prime}$ polymorphism is best suited for the study of association between PCR-RFLP alleles and the variation of general meat production traits within different pig breeds, while the other two sites can be used for studying the inter-breed variation of meat characteristics. Large numbers of commercial European pigs will be genotypes by use of the PCRRFLP tests for the MspI sites a and b (Fig. 4), and the resulting genotypes will be tested for the association with growth characteristics.

By using a cell hybrid panel, we assign $M Y O G$ to pig Chr 9, confirming a former mapping obtained by linkage analysis with an MspI RFLP (Archibald et al. 1995). In the human, MYOG maps to Chr 1q31-q41. Our results are in agreement with the conserved synteny between segments of human Chr 1 and porcine Chr 9, as has been demonstrated by linkage mapping of CR2 (Johansson et al. 1994) and Zoo-FISH analysis (Rettenberger et al. 1995a). From 
Table 2. Frequency of $M Y O G$ genotypes in seven pig breeds, based on three polymorphic $M s p$ I sites, in the promoter, second intron, and $3^{\prime}$ site of the gene.

\begin{tabular}{|c|c|c|c|c|c|c|c|c|c|c|}
\hline \multirow[b]{2}{*}{ Breed } & \multirow[b]{2}{*}{ No. ${ }^{a}$} & \multicolumn{3}{|c|}{ Promoter $^{\mathbf{b}}(\%)$} & \multicolumn{3}{|c|}{ Intron $2^{\mathrm{c}}(\%)$} & \multicolumn{3}{|c|}{$3^{\prime}$ end $^{b . d}(\%)$} \\
\hline & & $1.8 / 1.8$ & $1.8 / 2.3$ & $2.3 / 2.3$ & $2 / 2$ & $2 / 3$ & $3 / 3$ & $219 / 219$ & $353 / 219$ & $353 / 353$ \\
\hline Meishan & 11 & 9 & 36 & 55 & 9 & 36 & 55 & 0 & 0 & 100 \\
\hline Pietrain & 5 & 0 & 0 & 100 & 0 & 0 & 100 & 40 & 20 & 40 \\
\hline Duroc & 10 & 0 & 0 & 100 & 0 & 10 & 90 & 50 & 50 & 0 \\
\hline Wild pig & 10 & 0 & 0 & 100 & 0 & 0 & 100 & 60 & 40 & 0 \\
\hline$G Y^{\mathrm{e}}$ & 40 & 0 & 0 & 100 & 0 & 0 & 100 & 2.5 & 20 & 77.5 \\
\hline $\mathrm{DL}^{\mathrm{e}}$ & 20 & 0 & 0 & 100 & 0 & 10 & 90 & 30 & 40 & 30 \\
\hline Hampshire & 9 & 0 & 0 & 100 & 0 & 0 & 100 & 22 & 56 & 22 \\
\hline
\end{tabular}

Number of unrelated pigs tested.

b A $2.3-\mathrm{kb} / 1.8 \mathrm{~kg} \mathrm{MspI} \mathrm{polymorphism} \mathrm{is} \mathrm{detected} \mathrm{in} \mathrm{Meishan} \mathrm{pigs} \mathrm{by} \mathrm{Southern} \mathrm{blot} \mathrm{hybridization} \mathrm{to} \mathrm{the} \mathrm{MYOG} \mathrm{PCR} 1$ probe

c 2 denotes the absence, 3 the presence of the $M$ spl site at position 2394.

d PCR 4/MspI RFLP analsis detecting either a fragment of $353 \mathrm{bp}$ for the absence of the $M s p \mathrm{I}$ site, or fragments of 219 and $134 \mathrm{bp}$ for the presence of the MspI site.

e GY: Great Yorkshire; DL: Dutch Landrace.

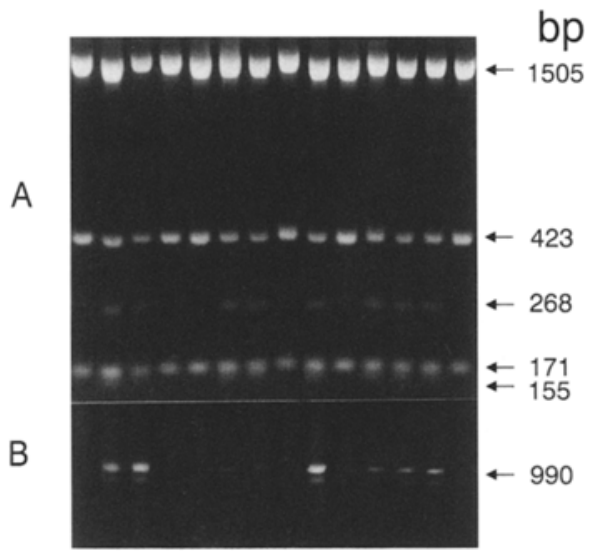

Fig. 3. Detection of two $M s p I$ polymorphisms at the pig $M Y O G$ gene locus in Meishan pigs; association between a polymorphic site in the promoter and a polymorphic site in the second intron. (A) PCR 1/MspI analysis, detecting an $M s p$ I polymorphism in the second intron of the MYOG gene at position 2394; the amplified fragment of 2099 bp is digested by $M s p \mathrm{I}$ resulting in four fragments of $1505,171,155$ and $268 \mathrm{bp}$, or in three fragments of 1505,171 , and $423 \mathrm{bp}$. (B). PCR6 analysis, showing the amplification of a fragment of $990 \mathrm{bp}$ that is coupled to the 268-bp fragment in $3 \mathrm{~A}$.

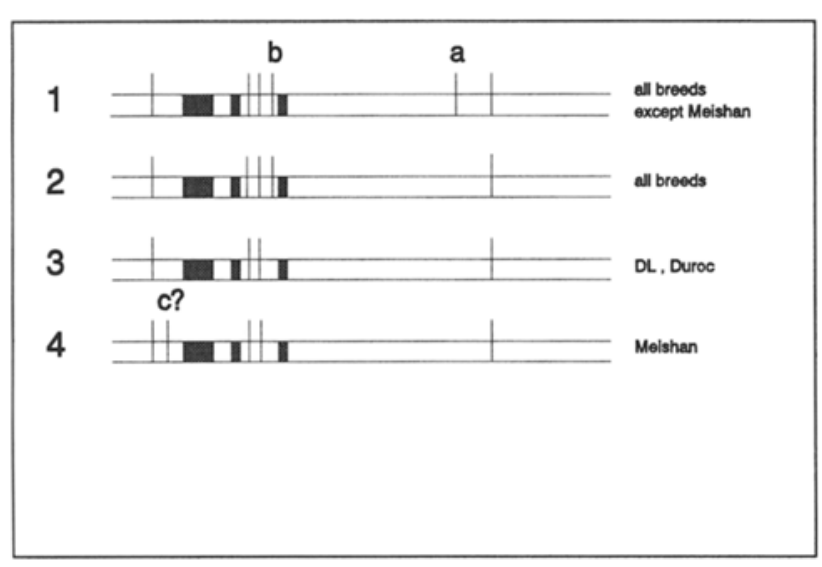

Fig. 4. Schematic representation of the four MYOG haplotypes that were distinguished in the pig breeds and crosses tested, based on the observed combinations of three polymorphic $M s p$ I fragments. The polymorphic sites are indicated by $a, b, c$. Shaded areas indicate coding sequences. Vertical lines indicate $M s p I$ sites.

the Zoo-FISH data, localization of MYOG on porcine Chr segment 9q21-qter can indirectly be predicted. Chromosomal assignment of MYOG offers the possibility to use a couple of microsatellites as an alternative or complementary set of polymorphic markers. A CA-
Table 3. Concordance percentages and values of the correlation coefficient phi $(\phi)$ for MYOG and pig chromosomes/reference loci in a pig-rodent somatic cell hybrid panel.

\begin{tabular}{llr}
\hline Chromosome/reference loci & con & $\phi$ \\
\hline 1//FNA & 67 & 0.41 \\
2/S0091 & 67 & 0.41 \\
3/APOB & 81 & 0.63 \\
4/S0001 & 52 & 0.04 \\
5/SO092 & 67 & 0.36 \\
6/RYR1 & 62 & 0.35 \\
7/TNFB & 76 & 0.51 \\
8/ALB & 71 & 0.37 \\
9/S0095 & 90 & 0.81 \\
10/S0038 & 81 & 0.60 \\
11/S0009 & 52 & 0.04 \\
12/GH & 81 & 0.59 \\
13/S0076 & 43 & -0.16 \\
14/DAO & 48 & 0.01 \\
15/S0088 & 38 & -0.23 \\
16/SO006 & 52 & -0.01 \\
17/ENDO & 62 & 0.28 \\
18/SO062 & 52 & 0.14 \\
X/SO022 & 46 & 0.08 \\
Y/SRY & 62 & 0.44 \\
\hline
\end{tabular}

repeat sequence of variable length (19 and 22 repeats) has been identified by Edmondson and coworkers (1992) and Yee and Rigby (1993) between positions -603 and -560 in the mouse MYOG promoter. We also identified a CA-repeat sequence within the porcine $M Y O G$ gene locus. However, since this CA-repeat is interrupted by $\mathrm{CCC}$ stretches, it is unlikely that this microsatellite will be polymorphic.

In summary, we have isolated the porcine $M Y O G$ gene, assigned it to Chr 9, and found four haplotypes based on $M Y O G$ polymorphisms. In a panel of 105 unrelated pigs and in several Meishan families, at least four $M Y O G$ alleles were identified, some of which were breed specific. PCR tests for rapid identification of these alleles were developed. This allows association studies with the growth and meat deposition performances of pigs.

Acknowledgments. The authors thank Dr. H. Geldermann (Hohenheim, Germany) and Dr. A.G. de Vries for providing the Wild Pig and the Hampshire blood, respectively. The Meishan pigs were from a population provided to Wageningen Agricultural University by Euribrid BV, Boxmeer (NL). This work was supported by the Dutch Ministry of Economic Affairs and by the pig breeding companies Cofok BV and VOC Nieuw Dalland BV. Patent (No. 95203623.4) was filed for the porcine MYOG gene sequence, the PCR tests to detect genetic variation within this gene, and the use of these tests in a breeding program.

\section{References}

Archibald AL, Haley CS, Brown JF, Couperwhite S, McQueen HA, Nicholson D, Coppieters W, Van de Weghe A, Stratil A, Winterø AK, Fredholm M, Larsen NJ, Nielsen VH, Milan D, Woloszyn N, Robic A, 
Dalens M, Riquet J, Gellin J, Caritez J-C, Burgaud G, Ollivier L, Bidanel J-P, Vaiman M, Renard C, Geldermann H, Davoli R, Ruyter D, Verstege EJM, Groenen MAM, Davies W, Høyheim B, Keiserud A, Andersson L, Ellegren H, Johansson M, Marklund L, Miller JR, Anderson Dear DV, Signer E, Jeffreys AJ, Moran C, Le Tissier P, Muladno, Rothschild MF, Tuggle CK, Vaske D, Helm J, Liu H-C, Rahman A, Yu T-P, Larson RG, Schmitz CB (1995) The PiGMaP consortium linkage map of the pig (Sus scrofa). Mamm Genome 6, 157-175

Braun T, Bober E, Buschhausen-Denker G, Kotz S, Grzeschik K-H, Arnold HH (1989a) Differential expression of myogenic determination genes in muscle cells: possible autoactivation by the Myf gene products. EMBO J 8, 3617-3625

Braun T, Buschhausen-Denker G, Bober E, Tannich E, Arnold HH (1989b) A novel human muscle factor related to but distinct from MyoD1 induces myogenic conversion in 10T1/2 fibroblasts. EMBO J 8, 701-709

Braun T, Bober E, Winter B, Rosenthal N, Arnold HH (1990) Myf-6, a new member of the human gene family of myogenic determination factors: evidence for a gene cluster on chromosome 12. EMBO J 9, 821-831

Briley GP, Reecy JM, Grant AL, Bidwell CA (1995) Cloning and expression of the porcine MYOG gene. Anim Biotechnol 6, 79-92

Chevalet $C$, Corpet $F$ (1986) Statistical decision rules concerning synteny or independence between markers. Cytogenet Cell Genet 43, 132-139

Edmondson DG, Olson EN (1989) A gene with homology to the myc similarity region of $\mathrm{MyoD} 1$ is expressed during myogenesis and is sufficient to activate the muscle differentiation program. Genes Dev 3, 628-640

Edmondson GD, Cheng T-C, Cserjesi P, Chakraborty T, Olson EN (1992) Analysis of the MYOG promoter reveals an indirect pathway for positive autoregulation mediated by the muscle-specific enhancer factor MEF-2. Mol Cell Biol 12, 3665-3677

Ernst CW, Vaske DA, Larson RG, Rothschild MF (1993) Rapid communication: $M s p I$ restriction fragment length polymorphism at the swine MYOG locus. J Anim Sci 71, 3479

Fujisawa-Sehara A, Nabeshima Y, Hosoda Y, Obinata T, Nabeschemia Y-I (1990) MYOG contains two domains conserved among myogenic factors. J Biol Chem 265, 15219-15223

Funk WD, Wright WD (1992) Cyclic amplification and selection of targets for multicomponent complexes: MYOG interacts with factors recognizing binding sites for basic helix-loop-helix, nuclear factor 1, myocytespecific enhancer-binding factor 2, and COMP1 factor. Proc Natl Acad Sci USA 89, 9484-9488

Händel SE, Stickland NC (1984) Muscle cellularity and its relationship with birth weight and growth. J Anat 139, 726

Händel SE, Stickland NC (1988) Catch-up growth in pigs: relationship with muscle cellularity. Anim Prod 46, 291-295

Hanset R, Micheaux C, Dessy-Doize C, Burtonboy G (1982) Studies on the 7 th rib cut in double-muscled and conventional cattle. Anatomical, historical and biochemical aspects. In: King JWB, Ménissier F (eds), Muscle hypertrophy of genetic origin and its use to improve beef production. The Hague: Marinus Nijhoff, pp 341-349

Hasty P, Bradley A, Morris JH, Edmondson DG, Venuti JM, Olson EN, Klein WH (1993) Muscle deficiency and neonatal death in mice with a targeted mutation in the MYOG gene. Nature 364, 501-506

Johansson M, Ellegren H, Marklund L, Coppieters W, Andersson L (1994) Linkage maps of porcine chromosomes 3,6, 9 based on 31 polymorphic markers. Mamm Genome 5, 785-790
Lyons GE, Buckingham ME (1992) Developmental regulation of myogenesis in the mouse. Dev Biol 3, 243-253

Montarras D, Chelly J, Bober E, Arnold H, Ott M-O, Gros F, Pinset C (1991) Developmental patterns in the expression of myf5, MyoD, myogenin and MRF4 during myogenesis. New Biol 3, 592-600

Nabeshima Y, Hanaoka K, Hayasaka M, Esumi E, Li S, Nanaka I, Nabeshima Y-I 1993) MYOG gene disruption results in perinatal lethality because of severe muscle defect. Nature 364, 532-535

Olson EN (1990) MyoD family: a paradigm for development? Genes Dev 4, 1454-1461

Rettenberg G, Fries R, Engel W, Scheit KH, Dolf G, Hameister H (1994a) Establishment of a partially informative porcine somatic cell hybird panel and assignment of the loci for transition protein 2 (TNP2) and protamine 1 (PRM1) to chromosome 3 and polyubiquitin (UBC) to chromosome 14. Genomics 21, 558-566

Rettenberger G, Burkhardt E, Adham IM, Engel W, Fries R, Klett C, Hameister H (1994b) Assignment of the Leydig-insulin like hormone to porcine chromosome $2 \mathrm{q} 12-\mathrm{q} 13$ by somatic cell hybrid analysis and fluorescence in situ hybridization. Mamm Genome 5, 307-309

Rettenberger G, Fredholm M, Fries R (1994c) Chromosomal assignment of porcine microsatellites by use of a somatic cell hybrid mapping panel. Anim Genet 25, 343-345

Rettenberger G, Klett C, Zechner U, Kunz J, Vogel W, Hameister H (1995a) Visualization of the conservation between pigs and humans by heterologous chromosomal painting. Genomics 26, 372-378

Rettenberger G, Bruch J, Beattie CW, Moran C, Fries R, Hameister H (1995b) Chromosomal assignment of 17 porcine microsatellites and genes by use of a somatic cell hybrid mapping panel. Anim Genet 26, 269-273

Salminen A, Braun T, Buchberger A, Jürs S, Winter B, Arnold HH (1991) Transcription of the muscle regulatory gene $M Y F 4$ is regulated by serum components, peptide growth factors and signaling pathways involving $G$ proteins. J Cell Biol 115, 905-917

Sambrook J, Fritsch EF, Maniatis T (1989) Molecular Cloning: A Laboratory Manuel, 2nd ed. (Cold Spring Harbor, NY: Cold Spring Harbor Laboratory Press)

Schwarz JJ, Chakraborty T, Martin J, Zhou J, Olson EN (1992) The basic region of MYOG cooperates with two transcription activation domains to induce muscle-specific transcription. Mol Cell Biol 12, 266-275

Southern EM (1975) Detection of specific sequences among DNA fragments separated by gel electrophoresis. J Mol Biol 98, 503-517

Swatland HJ, Kiefer NM (1974) Fetal development of double muscled condition in cattle. J Anim Sci 38, 752-757

Te Pas MFW, Visscher AH (1994) Genetic regulation of meat production by embryonic muscle formation-a review. J Anim Breed Genet 111, 404-412

Weintraub H, Davis R, Tapscott $S$, Thayer M, Krause M, Benezra R, Blackwell TK, Turner D, Rupp R, Hollenberg S, Zhang Y, Lassar A (1991) The myoD gene family: nodal point during specification of the muscle cell lineage. Science 251, 761-766

Wright WE, Sassoon DA, Lin VK (1989) MYOG, a factor regulating myogenesis, has a domain homologous to MyoD. Cell 56, 607-617

Yee S-P, Rigby PWJ (1993) The regulation of the MYOG gene expression during the embryonic development of the mouse. Genes Dev. 7, 1277 1289 